\title{
DEXTRAN AS A MEDIUM FOR THE DEMONSTRATION OF INCOMPLETE ANTI-Rh-AGGLUTININS (PRELIMINARY REPORT)
}

\author{
BY \\ RUNE GRUBB \\ From the Department of Bacteriology, the University, Lund, Sweden
}

(RECEIVEd FOR PUblication, FEBruary 18; 1949)

Dextran is a polysaccharide which is formed by Leuconostoc mesenteroides and has the composition (glucose- $\mathrm{H}_{2} \mathrm{O}$ ) n. A structural formula has been suggested by Levi and others (1942). Grönwall and Ingelman (1945) and Ingelman (1947) have shown that a partly hydrolysed 6 per cent solution of dextran in normal saline, of molecular weight approximately 100,000 , is a suitable plasma substitute, and it has been used as such in Sweden for some years.

\section{Experimental Observations}

A woman with anaemia due to a ruptured ectopic pregnancy had received $760 \mathrm{ml}$. of a solution of dextran just before the withdrawal of blood for determination of her $\mathrm{Rh}$ group by the rapid slide method. The cell suspension was made in the patient's own serum. It was known that the test sera used gave weak or no agglutination if the cells were suspended in serum that had been diluted with normal saline. In the present case the saline for dilution contained 6 per cent dextran, and strongly positive reactions were observed, the control (cell suspension only) showing no agglutination. The activity of incomplete anti-Rh-antibodies in a solution of dextran was therefore investigated.

Method.-Eleven sera with incomplete anti-Rhantibodies with titres between $1: 8$ to $1: 1,600$ were titrated against fresh cells of type $O R_{1} R_{1}$ and $O \mathrm{rr}$ in: (1) normal saline, (2) normal human serum (a mixture of ten sera), and (3) the solution of dextran used as a plasma substitute.

The technique used was as follows: tubes measured $8 \times 0.8 \mathrm{~cm}$. and $0.25 \mathrm{ml}$. volumes were placed in each tube. The cell suspensions were made in the same media as the serum dilutions. The tubes were incubated for four hours at $37^{\circ} \mathrm{C}$. They were gently shaken before reading and reactions were read by means of a hand lens. An irregular contour was not in itself considered evidence of a positive reaction.
Results.-Normal human serum and dextran had about the same enhancing effect on the incomplete agglutinins in the sera tested, and titres varied between 8 and 1,600. In saline medium agglutination was not observed beyond the serum dilution $1: 2$. The $R h$-negative cells were not agglutinated.

The enhancing effect of dextran on these agglutinins vanished below a concentration of 2.5 per cent dextran (the dilutions of dextran made in normal saline).

The enhancing effect of dextran on incomplete anti-Rh-agglutinins was also observed if a small volume of serum dilution and cell suspension (about $0.01 \mathrm{ml}$. each) are incubated for three hours at $37^{\circ} \mathrm{C}$. and the results read under the microscope. On such readings the cells in the control tubes often show a rouleaux-like arrangement, and if the salt concentration is increased to 1.5 per cent this pattern is more pronounced. If, on the other hand, the salt concentration is lowered, the cells are more evenly distributed, and at a concentration of 7 per cent dextran and 0.65 per cent $\mathrm{NaCl}$ no such pattern is observed although an enhancing effect is still retained.*

TABLE

TITRES AGAINST SHIGELLA BACILLI

\begin{tabular}{ll|c|c}
\hline & Normal saline & $6 \%$ dextran \\
\hline Chicken serum I & $\ldots$ & 400 & 3.200 \\
Chicken serum II & $\cdots$ & 200 & 3.200 \\
\hline
\end{tabular}

Sera from two chickens that had been immunized with Shigella bacilli were titrated in normal saline and in a medium of dextran (6 per cent dextran

* Swedish dextran was used throughout the experiments, but a sample of English dextran was examined and showed the enhancing sample of English dextran was examined and showed the enhancing
effect. However, this sample was more liable to give a rouleaux-like arrangement of the cells than the Swedish dextran. 
in 0.9 per cent $\mathrm{NaCl}$ ). The results (see Table) were read after incubation for twenty-four hours (four hours at $37^{\circ}$ C. and then twenty hours at room temperature).

Sera from five patients suffering from infection with Brucella abortus were titrated against this organism using saline and dextran as media. The titre of the agglutinins was not increased by the use of the dextran medium.

\section{Discussion}

Dextran gives a perfectly water-clear solution that keeps at room temperature and is free from natural agglutinins. The solution is commercially available, is relatively inexpensive, and may be autoclaved. Its composition is well defined and can therefore be kept constant. It is unquestionably active in revealing the agglutinating effect of incomplete anti-Rh-antibodies. These qualities of dextran make it worth while investigating the conditions which are optimal for the test in regard to concentrations, specificity, activity, and avidity. Such a study must include trials of dextran of differing molecular size with varying concentrations of different electrolytes against a large panel of cells and sera. Until this has been done the activity of dextran cannot justly be compared with the activity of other materials used in the demonstration of the incomplete antibodies.

Dextran is a polymer of glucose, but glucose is not active in producing an agglutinating activity of incomplete anti-Rh-antibodies (Diamond and Denton, 1945). As the molecular size of dextran can be varied without difficulty, a new approach is opened to the study of the physico-chemical conditions that are required for the demonstration of agglutinins in incomplete anti-Rh sera.

The preliminary character of the present study is obvious, and it is not suggested that dextran should be used exclusively in Rh-testing on the basis of these observations.

\section{Summary}

Incomplete anti-Rh-antibodies were found to be active in a solution of dextran.

\section{REFERENCES}

Diamond, L. K., and Denton, R. L. (1945). J. Lab. clin. Med., 30,

Grönwall, A., and Ingelman, B. (1945). Acta physiol. scand., 9, 1.

Ingelman, B. (1947). Acta chem. scand., 1, 731.

Lev, I., Hawkins, W. L., and Hibbert, H. (1942). J. Amer. chem. Soc., 64, 1959. 